\title{
Case report of a patient with Klinefelter syndrome treated with testosterone injections presenting with thrombotic thrombocytopenic purpura
}

\author{
Shira R. Saul ${ }^{1}$, Michael Jaker ${ }^{2}$ \\ 1. Department of Endocrinology, Diabetes and Bone Disease, Icahn School of Medicine at Mount Sinai, USA. \\ 2. Department of Medicine, New Jersey Medical School-Rutgers University, USA
}

Correspondence: Shira R. Saul. Address: Department of Endocrinology, Diabetes and Bone Disease, Icahn School of Medicine at Mount Sinai One Gustave L. Levy Place, NY, USA. Email: Shira.Saul@mssm.edu

Received: July 21, 2015

DOI : $10.5430 /$ crim.v2n4p38
Accepted: September 10, 2015 Online Published: September 28, 2015

URL: http://dx.doi.org/10.5430/crim.v2n4p38

\section{Abstract}

Thrombotic thrombocytopenic purpura (TTP) has been described as a pentad of thrombocytopenia, microangiopathic hemolytic anemia (MAHA), fluctuating neurologic signs, renal impairment and fever. Guidelines for treating patients with Klinefelter syndrome (KS), the most common chromosome aneuploidy, include testosterone replacement. We present the first case of adult with KS who presented with TTP after treatment with intramuscular testosterone injection. Whether or not the presentation is an association or coincidence is unknown, though in this report, we summarize the current understanding of testosterone supplementation in patients with KS. Original articles, case reports and reviews were obtained using a MEDLINE search between 1948 and 2013. Retrospective studies have concluded that in patients with KS there was an increased incidence of hematologic malignances with erythrocytosis being the only consistently documented hematologic abnormality associated with testosterone supplementation. A randomized, placebo-controlled study is needed to access the long-term effects of testosterone treatment in patients with KS.

\section{Keywords}

Klinefelter syndrome, Thrombotic thrombocytopenic purpura, Testosterone

\section{I ntroduction}

Thrombotic thrombocytopenic purpura (TTP), first described in 1925, as a pentad of thrombocytopenia, microangiopathic hemolytic anemia (MAHA), fluctuating neurologic signs, renal impairment and fever is a rare and potentially lethal disease with a mortality of $90 \%$ if left untreated. Klinefelter syndrome (KS) is the most common chromosomal aneuploidy and is characterized by hypergonadotropic hypogonadism. Guidelines for treating patients with KS include testosterone replacement. We present the first case of adult with a diagnosis of KS who presented with TTP after treatment with testosterone injections. 


\section{Case}

A 51-year-old man with a medical history of hypertension, type 2 diabetes mellitus and Klinefelter syndrome treated with intramuscular testosterone injections for 3 months prior to admission, presented to our emergency department following a motor vehicle accident. Upon arrival temperature was $38.4^{\circ} \mathrm{C}$. The patient had altered mental status and subsequently was intubated for airway protection. Initial lab results included white blood cell count 12,000/ul with $14 \%$ bands, hemoglobin $8.4 \mathrm{mg} / \mathrm{dl}$ (MCV $85.7 \mathrm{fL}$ ) and platelet count of 5,000/ul (MPV $7.5 \mathrm{fL}$ ). Direct Coombs was negative, lactate dehydrogenase $1247 \mathrm{u} / \mathrm{L}$ and the reticulocyte count was 6.1\%. Additional labs included a blood-urea nitrogen $25 \mathrm{mg} / \mathrm{dl}$, creatinine $1.1 \mathrm{mg} / \mathrm{dl}$, total bilirubin $2.2 \mathrm{mg} / \mathrm{dl}$, direct bilirubin $0.4 \mathrm{mg} / \mathrm{dl}$ and lactic acid $3.0 \mathrm{mEq} / \mathrm{L}$. Coagulation studies were negative as was HIV ELISA. Peripheral blood smear revealed schistocytes confirming the diagnosis of TTP. Daily plasma exchange was begun, and after five days of this treatment platelet count had reached 156,000/ul. The patient confirmed that he had no exposure to quinine and the only new medication he had received was the testosterone injections. ADAMTS13 (A Disintegrin And Metalloproteinase with a ThromboSpondin type 1 motif, member 13) activity level returned at 32\% (Blood Center of Wisconsin; $<67 \%$ abnormal, $<5 \%$ severe deficiency) with anti-ADAMTS13 antibody of 13 (Blood Center of Wisconsin; < 18 negative, 19-27 indeterminate, > 28 positive). Following an extensive hospital course our patient was discharged home, clinically improved on a tapering dose of prednisone.

\section{Discussion}

TTP, first described in 1925, is reported to have an annual incidence of 4 to 11 cases per million people with a mortality of $90 \%$ if left untreated ${ }^{[1,2]}$. The syndrome, initially classified as a pentad of thrombocytopenia, MAHA, fluctuating neurologic signs, renal impairment and fever was later revised to include anyone with thrombocytopenia and MAHA ${ }^{[3]}$. Pathogenesis includes a deficiency of ADAMTS13, a von Willebrand Factor (vWF) cleaving metalloprotease protein ${ }^{[4,5]}$. Measurement of pre-treatment ADAMTS13 and ADAMTS13 IgG antibody is helpful to confirm the diagnosis, although due to the high mortality, treatment should be initiated within 4-8 hours of high clinical suspicion of TTP ${ }^{[1,6]}$. It is important to note that cohort studies have shown the sensitivity of the ADAMTS13 testing ranges from 33 to 100 percent, and that patients with TTP may have normal levels ${ }^{[7]}$. TTP has been classified into congenital and acquired, the latter being associated with pregnancy, HIV, organ transplant, pancreatitis, malignancy, drug-induced and most commonly, idiopathic ${ }^{[8]}$. Drugs documented to induce TTP include quinine, mitomycin-C, cyclosporine, clopidogrel and ticlopidine ${ }^{[9]}$. Oral contraceptive pills and estrogen hormone replacement therapy are known to provoke thromboembolic events and have been suggested to have an association with TTP ${ }^{[10,11]}$. Westerlund et al. investigated this correlation by measuring clotting factors throughout an in-vitro fertilization (IVF) cycle. As estradiol levels increased so did levels of Factor VIII, vWF activity and antigen; levels of ADAMTS13 activity and antigen decreased ${ }^{[12]}$. The primary hematologic side effect of testosterone supplementation documented is erythrocytosis, with guidelines advising hematocrit testing initially every three months followed by annual surveillance ${ }^{[13-15]}$. Thrombocytopenia has not been associated with testosterone supplementation.

KS, first described in 1942 has an estimated incidence of 1 per 500 births with a prevalence of 150 per 100,000 live-born males ${ }^{[15]}$. It is the most common chromosome aneuploidy, is characterized by hypergonadotropic hypogonadism and is confirmed by karyotype analysis ${ }^{[15,16]}$. Pathogenesis involves non-disjunction during germ or early embryotic cell divisions and thus has numerous chromosomal aberrations, the most common being $47, \mathrm{XXY}{ }^{[16]}$. KS is widely under-diagnosed, and has been associated with increased mortality both overall and from secondary associated medical conditions ${ }^{[15]}$. These conditions include motor, cognitive and behavior dysfunction, osteoporosis, metabolic syndrome and diabetes mellitus ${ }^{[15]}$. There is a higher risk of developing certain malignancies including mediastinal cancers in children ${ }^{[17]}$ and breast cancer and non-Hodgkin's lymphoma in adults ${ }^{[18]}$. Regarding hematologic associations, retrospective studies and literature reviews have concluded that KS was more likely "discovered" in hematologic malignances and thus larger studies are needed ${ }^{[19,20]}$. 
Testosterone, the first line agent treatment of KS has been associated with erythrocytosis, prostate enlargement, and reduced fertility ${ }^{[14]}$. Clinical guidelines advise against treatment of men with metastatic prostate cancer, breast cancer, unevaluated prostate nodule, prostate-specific antigen greater $4 \mathrm{ng} / \mathrm{ml}$, hematocrit greater than $50 \%$ and poorly controlled heart failure ${ }^{[15]}$. Randomized, placebo controlled studies of long term testosterone supplementation in KS patients have not been published, though literature has described improved sexual function and mood, increase in lean body mass with a decrease in fat mass ${ }^{[21]}$. Interestingly one study in 2000 published by Kocar et al. observed that in Klinefelter patients treated with testosterone immunologic parameters including immunoglobulins and interleukins decreased after treatment ${ }^{[22]}$. Erythrocytosis is the only consistently documented hematologic abnormality that has been associated with testosterone supplements ${ }^{[13-15]}$. We are reporting the first adult case of patient with Klinefelter syndrome (XXY) treated with testosterone injections who presented with thrombotic thrombocytopenic purpura. Of note there is one reported case report documenting a 13-year-old XXYY child who died from TTP, however there is no mention of testosterone use ${ }^{\text {[23] }}$.

\section{Conclusion}

In summary we present a 51-year-old man with recent diagnosis of KS who was undergoing treatment with testosterone injections and presented with TTP. Whether the testosterone injections were the culprit remains unknown, however re-challenging him with testosterone supplementation poses too much of a risk. Interestingly, studies in women who have received testosterone have shown that although testosterone effects endothelial marker proteins including vWF, these effects do not change the endothelial cell functioning ${ }^{[24,25]}$. A randomized, placebo-controlled study is needed to access the long-term effects of testosterone treatment in Klinefelter patients. Until then a correlation, if any between Klinefelter patients treated with testosterone and TTP remains unknown. With the increase in number of patients with KS receiving testosterone supplementation hopefully we will able to determine if a causal relationship exists.

\section{References}

[1] Scully M, Yarranton H, Liesner R, et al. Regional UK TTP registry: correlation with laboratory ADAMTS 13 analysis and clinical features. Br J Haematol. 2008; 142(5): 819-26. PMid:18637802 http://dx.doi.org/10.1111/j.1365-2141.2008.07276.x

[2] Terrell DR, Williams LA, Vesely SK, et al. The incidence of thrombotic thrombocytopenic purpura-hemolytic uremic syndrome: all patients, idiopathic patients, and patients with severe ADAMTS-13 deficiency. Journal of Thrombosis and Haemostasis. 2005; 3(7): 1432-1436. PMid:15978100 http://dx.doi.org/10.1111/j.1538-7836.2005.01436.x

[3] Galbusera M, Noris M, Remuzzi G. Thrombotic thrombocytopenic purpura-then and now. Semin Thromb Hemost. 2006; 32(2): 81-9. PMid:16575682 http://dx.doi.org/10.1055/s-2006-939763

[4] Furlan M, Robles R, Galbusera M, et al. Von Willebrand factor-cleaving protease in thrombotic thrombocytopenic purpura and the hemolytic-uremic syndrome. N Engl J Med. 1998; 339(22): 1578-84. PMid:9828245 http://dx.doi.org/10.1056/NEJM199811263392202

[5] Tsai HM, Lian EC. Antibodies to von Willebrand factor-cleaving protease in acute thrombotic thrombocytopenic purpura. N Engl J Med. 1998; 339(22): 1585-94. PMid:9828246 http://dx.doi.org/10.1056/NEJM199811263392203

[6] George JN, Al-Nouri ZL. Diagnostic and therapeutic challenges in the thrombotic thrombocytopenic purpura and hemolytic uremic syndromes. Hematology Am Soc Hematol Educ Program. 2012; 2012: 604-9.

[7] Lammle B, Kremer Hovinga JA, Alberio L. Thrombotic thrombocytopenic purpura. J Thromb Haemost. 2005; 3(8): $1663-75$. PMid:16102032 http://dx.doi.org/10.1111/j.1538-7836.2005.01425.x

[8] Scully M, Hunt BJ, Benjamin S, et al. British Committee for Standards in, Guidelines on the diagnosis and management of thrombotic thrombocytopenic purpura and other thrombotic microangiopathies. Br J Haematol. 2012; 158(3): 323-35. PMid:22624596 http://dx.doi.org/10.1111/j.1365-2141.2012.09167.x

[9] Zakarija A, Bennett C. Drug-induced thrombotic microangiopathy. Semin Thromb Hemost. 2005; 31(6): 681-90. PMid:16388419 http://dx.doi.org/10.1055/s-2005-925474

[10] Holdrinet RS, de Pauw BE, Haanen C. Hormonal dependent thrombotic thrombocytopenic purpura (TTP). Scand J Haematol. 1983; 30(3): 250-6. PMid:6682996 http://dx.doi.org/10.1111/j.1600-0609.1983.tb01487.x

[11] Snir M, S Cohen, Ben-Sira I, et al. Retinal manifestations of thrombotic thrombocytopenic purpura (TTP) following use of contraceptive treatment. Ann Ophthalmol. 1985; 17(2): 109-12. PMid:4039547 
[12] Westerlund E, Antovic A, Hovatta O, et al. Changes in von Willebrand factor and ADAMTS13 during IVF. Blood Coagul Fibrinolysis. 2011; 22(2): 127-31. PMid:21192251 http://dx.doi.org/10.1097/MBC.0b013e32834363ea

[13] Fernandez-Balsells MM, Murad MH, Lane M, et al, Clinical review 1: Adverse effects of testosterone therapy in adult men: a systematic review and meta-analysis. J Clin Endocrinol Metab. 2010; 95(6): 2560-75. PMid:20525906 http://dx.doi.org/10.1210/jc.2009-2575

[14] Bhasin S, Cunningham GR, Hayes FJ, et al. Testosterone therapy in men with androgen deficiency syndromes: an Endocrine Society clinical practice guideline. J Clin Endocrinol Metab. 2010; 95(6): 2536-59. PMid:20525905 http://dx.doi.org/10.1210/jc.2009-2354

[15] Groth KA, Skakkebaek A, Host C, et al. Clinical review: Klinefelter syndrome-a clinical update. J Clin Endocrinol Metab. 2013; 98(1): 20-30. PMid:23118429 http://dx.doi.org/10.1210/jc.2012-2382

[16] Lanfranco F, Kamischke A, Zitzmann M, et al. Klinefelter's syndrome. Lancet. 2004; 364(9430): 273-83. http://dx.doi.org/10.1016/S0140-6736(04)16678-6

[17] Hasle H, Mellemgaard A, Nielsen J, et al. Cancer incidence in men with Klinefelter syndrome. Br J Cancer. 1995; 71(2): 416-20. PMid:7841064 http://dx.doi.org/10.1038/bjc.1995.85

[18] Swerdlow AJ, Schoemaker MJ, Higgins CD, et al. Cancer incidence and mortality in men with Klinefelter syndrome: a cohort study. J Natl Cancer Inst. 2005; 97(16): 1204-10. PMid:16106025 http://dx.doi.org/10.1093/jnci/dji240

[19] Keung YK, Buss D, Chauvenet A, et al. Hematologic malignancies and Klinefelter syndrome. a chance association? Cancer Genet Cytogenet. 2002; 139(1): 9-13. http://dx.doi.org/10.1016/S0165-4608(02)00626-X

[20] Eberl MM, Baer MR, Mahoney MC, et al. Unsuspected Klinefelter syndrome diagnosed during oncologic evaluation: a case series. J Am Board Fam Pract. 2005; 18(2): 132-9. PMid:15798142 http://dx.doi.org/10.3122/jabfm.18.2.132

[21] Wang C, Cunningham G, Dobs A, et al. Long-term testosterone gel (AndroGel) treatment maintains beneficial effects on sexual function and mood, lean and fat mass, and bone mineral density in hypogonadal men. J Clin Endocrinol Metab. 2004; 89(5): 2085-98. PMid:15126525 http://dx.doi.org/10.1210/jc.2003-032006

[22] Kocar IH, Yesilova Z, Ozata M, et al. The effect of testosterone replacement treatment on immunological features of patients with Klinefelter's syndrome. Clin Exp Immunol. 2000; 121(3): 448-52. PMid:10973715 http://dx.doi.org/10.1046/j.1365-2249.2000.01329.x

[23] Tartaglia N, Davis S, Hench A, et al. A new look at XXYY syndrome: medical and psychological features. Am J Med Genet A. 2008; 146A(12): 1509-22. PMid:18481271 http://dx.doi.org/10.1002/ajmg.a.32366

[24] van Kesteren PJ, Kooistra T, Lansink M, et al. The effects of sex steroids on plasma levels of marker proteins of endothelial cell functioning. Thromb Haemost. 1998; 79(5): 1029-33. PMid:9609242

[25] Gooren LJ, Giltay EJ. Review of studies of androgen treatment of female-to-male transsexuals: effects and risks of administration of androgens to females. J Sex Med. 2008; 5(4): 765-76. PMid:17971101 http://dx.doi.org/10.1111/j.1743-6109.2007.00646.x 